\title{
Characterization of Novel Salt-Tolerant Esterase Isolated from the Marine Bacterium Alteromonas sp. 39-G15
}

\author{
Seok-Jae Won ${ }^{\dagger}$, Han Byeol Jeong ${ }^{\dagger}$, and Hyung-Kwoun Kim* \\ Department of Biotechnology, The Catholic University of Korea, Bucheon 14662, Republic of Korea
}

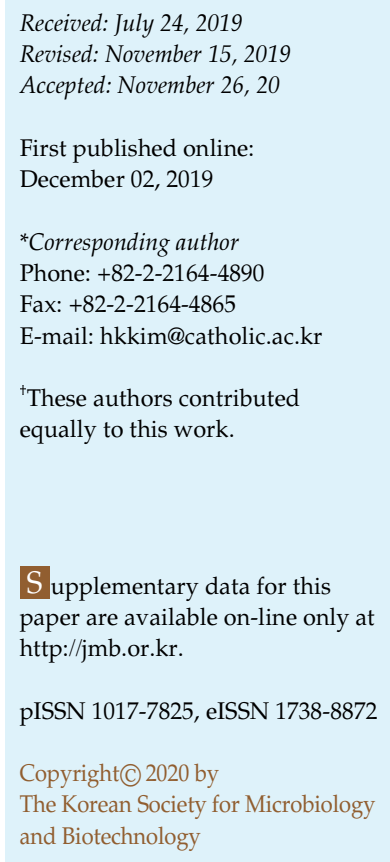

S upplementary data for this paper are available on-line only at http://jmb.or.kr.

pISSN 1017-7825, eISSN 1738-8872

Copyright(C) 2020 by

The Korean Society for Microbiology and Biotechnology

\begin{abstract}
An esterase gene, estA1, was cloned from Alteromonas sp. 39-G1 isolated from the Beaufort Sea. The gene is composed of 1,140 nucleotides and codes for a 41,190 Da protein containing 379 amino acids. As a result of a BLAST search, the protein sequence of esterase EstA1 was found to be identical to Alteromonas sp. esterase (GenBank: PHS53692). As far as we know, no research on this enzyme has yet been conducted. Phylogenetic analysis showed that esterase EstA1 was a member of the bacterial lipolytic enzyme family IV (hormone sensitive lipases). Two deletion mutants ( $\Delta 20$ and $\Delta 54)$ of the esterase EstA1 were produced in Escherichia coli BL21 (DE3) cells with part of the N-terminal of the protein removed and His-tag attached to the C-terminal. These enzymes exhibited the highest activity toward $p$-nitrophenyl $(p N P)$ acetate $\left(C_{2}\right)$ and had little or no activity towards $p$ NP-esters with acyl chains longer than $C_{6}$. Their optimum temperature and $\mathrm{pH}$ of the catalytic activity were $45^{\circ} \mathrm{C}$ and $\mathrm{pH} 8.0$, respectively. As the $\mathrm{NaCl}$ concentration increased, their enzyme activities continued to increase and the highest enzyme activities were measured in $5 \mathrm{M} \mathrm{NaCl}$. These enzymes were found to be stable for up to $8 \mathrm{~h}$ in the concentration of 3-5 M NaCl. Moreover, they have been found to be stable for various metal ions, detergents and organic solvents. These salt-tolerant and chemical-resistant properties suggest that the enzyme esterase EstA1 is both academically and industrially useful.
\end{abstract}

Keywords : Alteromonas, family IV esterase, salt tolerance

\section{Introduction}

Esterase (E.C. 3.1.1.1) and lipase (E.C. 3.1.1.3) are industrial enzymes that catalyze hydrolysis and the transesterification reactions of fatty acid esters [1]. These enzymes are serine hydrolase with serine amino acids at the active site. Many serine hydrolases have been studied for their 3D protein structures, and most enzymes are known to share a common structure, the $\alpha / \beta$ hydrolase fold [2]. The active site has a catalytic triad (Ser-His-Asp/Glu), and the active serine is in the well-conserved pentapeptide sequence (Glyx-Ser-x-Gly) [3] and is considered to perform nucleophilic attacks during enzyme reaction as part of the nucleophilic elbow [4]. Esterase prefers hydrolyzing ester bonds of fatty acids with short carbon chains, and lipase prefers hydrolyzing ester bonds of fatty acids with long carbon chains [5].

Esterases and lipases are classified into eight families according to protein sequence, conserved amino acid sequence motif and biochemical property [6]. Among them, some bacterial esterases and lipases are classified as family IV, along with hormone-sensitive lipases (HSL) [7]. Family IV enzymes generally consist of two domains: the cap domain at the $\mathrm{N}$-terminus and the catalytic domain at the C-terminus [8, 9]. Cap domains generally have two $\alpha$ helices and one loop structure, covering the active site of the catalyst domain. Various family IV esterases and lipases are found in various environments such as hot springs [10], deep seas [11], the Arctic sediments [12], marine sediments [13], and soils [14].

Microorganisms living in extreme environments are a source of industrially useful enzymes [15, 16]. Extreme 
microorganisms produce extreme enzymes, which have high activity and stability in extreme environments. Interestingly, some extreme enzymes exhibit high activity under more than two extreme conditions [17-19]. The enzymes derived from marine microorganisms have attracted the attention of many researchers because they maintain high enzyme activity even under severe conditions including high temperature, low temperature, and high $\mathrm{pH}$ or low $\mathrm{pH}[20,21]$. In addition, these enzymes have high activity under organic solvents, high salinity and low water activity environments [22], suggesting the potential to be used as industrial biocatalysts [23].

Esterases and lipases have been applied widely in the detergent, biodiesel, food, and pulp and paper industries [24-27]. Lipolytic enzymes derived from Burkholderia, for example, are used in biodiesel production [28]. These enzymes can be used for transesterification of waste oils with short chain alcohol in high levels of methanol solvents. Other lipolytic enzymes can be used in biological purification of contaminated environments, especially in low temperature environments, such as oil spills [29].

In this study, an esterase gene (estA1) was cloned from Alteromonas sp. 39-G1 isolated from the Beaufort Sea. We produced two deletion mutants $(\Delta 20$ and $\Delta 54)$ of the esterase EstA1 and characterized their enzymatic properties in this research.

\section{Materials and Methods}

\section{Materials}

Acetonitrile, 2-propanol, ampicillin, tributyrin, p-nitrophenyl ( $p$-NP) acetate $\left(\mathrm{C}_{2}\right), p$-NP butyrate $\left(\mathrm{C}_{4}\right), p$-NP caprylate $\left(\mathrm{C}_{8}\right)$, lithium chloride, nickel chloride, sodium dodecyl sulfate, dithiothreitol, 2mercaptoethanol, Triton X-100 and phenylmethylsulfonyl fluoride were purchased from Sigma Aldrich Co. (USA). Dimethyl sulfoxide, cobalt chloride hexahydrate, magnesium sulfate, potassium chloride, calcium chloride, sodium chloride, zinc chloride, chloroform, cyclohexane, n-hexane and acetone were purchased from Junsei Co. (Japan). $p$-NP caproate $\left(\mathrm{C}_{6}\right)$ was purchased from Tokyo Chemical Industry Co. (Japan). Methanol and ethanol were purchased from Merck Chemical Co. (Germany), and $\beta$-Dthiogalactopyranoside was purchased from Duchefa Biochemie B.V. Co. (The Netherlands). Copper sulfate was purchased from Kanto Chemical Co. (Japan). X-gal was purchased from Promega (USA). Ni-NTA agarose was purchased from Qiagen (Germany). We were provided with a lipolytic bacterial strain (No. 39-G1) isolated from the Arctic Beaufort Sea (70-56-1581 N, 136-25-1178 W) by Korea Polar Research Institute.

\section{Shotgun Cloning of estA1 Esterase Gene}

The chromosomal DNA was extracted from Alteromonas sp. 39-
G1 strain using a genomic DNA extraction kit (iNtRON Biotechnology, Korea). The isolated chromosomal DNA was digested with EcoRI, ligated with pUC19 vector and transformed into E. coli DH5 $\alpha$. Among about 10,000 colonies, 13 colonies had lipolytic activity on tributyrin (TBN)-LB agar plate. These colonies were cultured in LB broth and recombinant plasmids were extracted with a LaboPass DNA Mini Kit (Cosmogenetech, Korea). Insert DNAs were sequenced and one functional esterase gene was found and designated as est $A 1$ gene.

\section{EstA1 Protein Sequence Analysis and Structure Homology Modeling}

The EstA1 protein sequence was predicted from the estA1 nucleotide sequence using the DNASTAR program. The position and length of the signal sequence of the EstA1 protein was predicted by the SignalP 4.1 Server (http://www.cbs.dtu.dk/ services/SignalP-4.1/). The search and similarity calculation of some proteins similar to the EstA1 protein were performed in the BLASTp programs (http://www.ncbi.nlm.nih.gov/BLAST/). Multiple sequence alignment with similar esterase sequences was performed using ClustalW method and aligned sequences were rendered at ESPript 3.0 web (http://espript.ibcp.fr/ESPript/ ESPript/). Phylogenetic tree was constructed using the neighborjoining method with 1000 bootstrap replications implemented by the phylogeny package MEGA 5.2.

The 3D structure of the EstA1 protein was constructed by SWISS-MODEL (https://swissmodel.expasy.org/) using the crystal structure (PDB: 4Q3O) of MGS-MT1, an alpha/beta hydrolase enzyme isolated from a Lake Matapan deep-sea metagenome library as templates and presented using PyMOL program.

\section{Expression and Purification of the Recombinant Esterase EstA1}

Three PCR products (WT, $\Delta 20$, and $\Delta 54$ ) amplified by primers (Table S1) were inserted into the pGEM-T vector (Promega, USA). These recombinant plasmids were digested with NdeI and XhoI and the insert DNA fragments were ligated into pET22 vector. The resulting recombinant plasmids were transformed into $E$. coli BL21 (DE3) cells. Transformed cells were inoculated in $200 \mathrm{ml} \mathrm{LB}$ medium containing ampicillin $(100 \mu \mathrm{g} / \mathrm{ml})$ and cultured at $37^{\circ} \mathrm{C}$ to $230 \mathrm{rpm}$. The E. coli BL21 (DE3) cells were induced to produce the recombinant proteins with $1 \mathrm{mM}$ IPTG at $16^{\circ} \mathrm{C}$ for $16 \mathrm{~h}$ after the $\mathrm{OD}_{600}$ reached 0.6. The cells were harvested by centrifugation $(4,000 \times g$ for $10 \mathrm{~min})$ and resuspended in lysis buffer $(50 \mathrm{mM}$ $\mathrm{NaH}_{2} \mathrm{PO}_{4}, 300 \mathrm{mM} \mathrm{NaCl}$, and $10 \mathrm{mM}$ imidazole, $\mathrm{pH}$ 8.0), then disrupted by ultrasonicator and the cell-free extract was obtained by centrifugation $(12,000 \times g$, for $10 \mathrm{~min})$.

The cell-free extract was applied to the Ni-NTA agarose affinity chromatography column that has been previously equilibrated with the lysis buffer. The unbound proteins were removed by washing the column with washing buffer $\left(50 \mathrm{mM} \mathrm{NaH} \mathrm{PO}_{4}\right.$, $300 \mathrm{mM} \mathrm{NaCl}$, and $20 \mathrm{mM}$ imidazole, $\mathrm{pH}$ 8.0) and the esterase EstA1 was eluted with elution buffer $\left(50 \mathrm{mM} \mathrm{NaH} \mathrm{PO}_{4}, 300 \mathrm{mM}\right.$ $\mathrm{NaCl}$, and $500 \mathrm{mM}$ imidazole, $\mathrm{pH}$ 8.0). The purified esterase EstA1 
was loaded onto the FPLC system equipped with a Superpose ${ }^{\mathrm{TM}}$ 12 10/300 GL gel permeation column and eluted using elution buffer $\left(50 \mathrm{mM} \mathrm{NaH} \mathrm{PO}_{4}\right.$ and $300 \mathrm{mM} \mathrm{NaCl}, \mathrm{pH}$ 8.0). Protein concentration was measured by Bradford assay and the purity was analyzed by SDS-PAGE.

\section{Enzyme Assay}

Esterase activity assay was performed with $p$ NP-esters as substrates, and the production of $p$-nitrophenol was measured using $405 \mathrm{~nm}$ absorbance. One unit of esterase activity was defined as $1 \mu \mathrm{mol}$ of $p$-nitrophenol liberated per min under standard assay conditions $\left(\mathrm{pH} 8.0,40^{\circ} \mathrm{C}, 3 \mathrm{~min}\right)$. The assay was carried out in $1 \mathrm{ml}$ reaction mixture containing $950 \mu \mathrm{l}$ of $50 \mathrm{mM}$ Tris- $\mathrm{HCl}$ ( $\mathrm{pH} 8.0), 40 \mu \mathrm{l}$ of ethanol, and $10 \mu \mathrm{l}$ of $10 \mathrm{mM} p$ NP-esters dissolved in acetonitrile solvent.

\section{Characterization of Esterase EstA1}

The substrate specificity of purified esterase EstA1 was determined in standard conditions $\left(\mathrm{pH} 8.0,40^{\circ} \mathrm{C}, 3 \mathrm{~min}\right)$ in $50 \mathrm{mM}$ Tris- $\mathrm{HCl}$ buffer containing $10 \mathrm{mM}$ of $p$ NP-esters $\left(\mathrm{C}_{2}-\mathrm{C}_{8}\right)$. The optimal $\mathrm{pH}$ for enzyme activity was determined at $40^{\circ} \mathrm{C}$ in buffers with $\mathrm{pH}$ range from 6.0 to 9.5 and $p$ NP-butyrate $\left(\mathrm{C}_{4}\right)$ was used as substrate in $\mathrm{pH}$ effect assay. The $\mathrm{pH}$ stability of the enzyme was tested by measuring the residual activity after 30 min-incubation in various $\mathrm{pH}$ buffers; $\mathrm{pH} 5.0-6.0,50 \mathrm{mM}$ sodium acetate; $\mathrm{pH}$ 6.08.0, $50 \mathrm{mM}$ potassium phosphate; $\mathrm{pH} 8.0-9.0,50 \mathrm{mM}$ Tris- $\mathrm{HCl} ; \mathrm{pH}$ 9.0-10.5, $50 \mathrm{mM}$ carbonate-bicarbonate. The optimal temperature for enzyme activity was determined over the range of $0-70^{\circ} \mathrm{C}$ in Tris-HCl buffer ( $\mathrm{pH} 8.0)$ and $p$ NP-butyrate $\left(\mathrm{C}_{4}\right)$ was used as a substrate. The temperature stability of the enzyme was tested by treating enzyme at various temperatures for the indicated time and measuring residual activity.

To investigate the effect of various organic solvents (DMSO, methanol, ethanol, acetonitrile, acetone, isopropanol, cyclohexane, and n-hexane) on the mutant enzymes, the enzymes were incubated in various organic solvents $(15,30,50 \%, \mathrm{v} / \mathrm{v})$ for $30 \mathrm{~min}$ at $30^{\circ} \mathrm{C}$ and the residual enzyme activities were measured in standard conditions ( $\mathrm{pH} 8.0,40^{\circ} \mathrm{C}, 3 \mathrm{~min}$ ). $p \mathrm{NP}$-acetate $\left(\mathrm{C}_{2}\right)$ was used as a substrate. The enzyme activity of the esterase EstA1 solution without solvent was set to $100 \%$.

Enzyme activity was also determined in $1 \mathrm{mM}$ (or $5 \mathrm{mM}$ ) metal ions $\left(\mathrm{Li}^{+}, \mathrm{Na}^{+}, \mathrm{K}^{+}, \mathrm{Mg}^{2+}, \mathrm{Ca}^{2+}, \mathrm{Co}^{2+}, \mathrm{Ni}^{2+}, \mathrm{Zn}^{2+}\right.$, and $\left.\mathrm{Cu}^{2+}\right), 1 \mathrm{mM}$ (or $5 \mathrm{mM}$ ) inhibitors (dithiothreitol, $\beta$-mercaptoethanol, glutathione disulfide, EDTA, phenylmethylsulfonyl fluoride), and $0.1 \%$ (or $0.5 \%$ ) detergents (sodium dodecyl sulfate, Tween-20, Tween-40, Tween80 , and Triton $\mathrm{X}-100)$. $p \mathrm{NP}$-acetate $\left(\mathrm{C}_{2}\right)$ was used as a substrate.

The effect of $\mathrm{NaCl}$ on enzyme activity was determined at $40^{\circ} \mathrm{C}$ in Tris- $\mathrm{HCl}$ buffer ( $\mathrm{pH}$ 8.0). Increasing concentrations ( 0 to $5 \mathrm{M}$ ) of $\mathrm{NaCl}$ were used and $p \mathrm{NP}$-acetate $\left(\mathrm{C}_{2}\right)$ was used as a substrate. To investigate its stability toward the high concentration of $\mathrm{NaCl}$, enzyme was incubated in Tris- $\mathrm{HCl}$ buffer ( $\mathrm{pH} 8.0$ ) containing high concentration $(3,4$, and $5 \mathrm{M})$ of $\mathrm{NaCl}$ for $8 \mathrm{~h}$ and the residual enzyme activities were measured.
In all experiments, we performed enzyme activity measurements three times and calculated the mean value and presented the standard deviation in the figures.

\section{Results and Discussion}

\section{Strain Identification}

Based on the 16S rRNA sequence analysis (Fig. S1), the strain 39-G1 was classified into the genus Alteromonas and designated as Alteromonas sp. 39-G1. The phylogenetic tree created by the Clustal W method of the DNASTAR program revealed the same classification (Fig. S2).

\section{Esterase EstA1 Gene Cloning}

The genomic DNA was extracted from Alteromonas sp. 39-G1 and DNA fragments were inserted into the pUC19 plasmid and the recombinant plasmid library was transformed into E. coli DH5 $\alpha$. Clones showing clear halo in tributyrin/LB agar plate were found, and the recombinant plasmids obtained from the clones were analyzed. The sequence analysis revealed that one open reading frame (ORF), which is presumed to be an esterase/lipase gene, was found.

\section{Sequence Analysis and Structural Modeling of Esterase EstA1}

The ORF consists of 1,140 nucleotides and codes 379 amino acids (Fig. S3). A BLAST search revealed that this protein belongs to the esterase family IV. We decided to call this enzyme 'esterase EstA1.' The phylogenetic tree was constructed using this esterase EstA1 and other esterases belonging to family IV (Fig. S4), and this esterase EstA1 was found to be identical with Alteromonas sp. esterase (GenBank PHS53692.1). Although this protein sequence has already been reported, we have decided to study it because there has been no report on this protein as far as we know.

As a result of multiple sequence alignment of the esterase EstAl with other esterases already identified in 3D structures, the conserved amino acid sequence (HGG and GTSAG motif) was confirmed and the catalytic triad was predicted as S221, D317 and H347 (Fig. 1).

To construct the structure homology model of esterase EstA1, we used the uncultured bacterium Mgs-mt1 esterase (PDB: 4Q3O) [30] as a template structure. As expected, the esterase EstA1 has an $\alpha / \beta$ hydrolase fold structure with a $\beta$ sheet at the center and several $\alpha$ helixes surrounding back and forth (Fig. S5). The above-mentioned S221, D317 and H347 are located about $3 \AA$ away from each other at the 


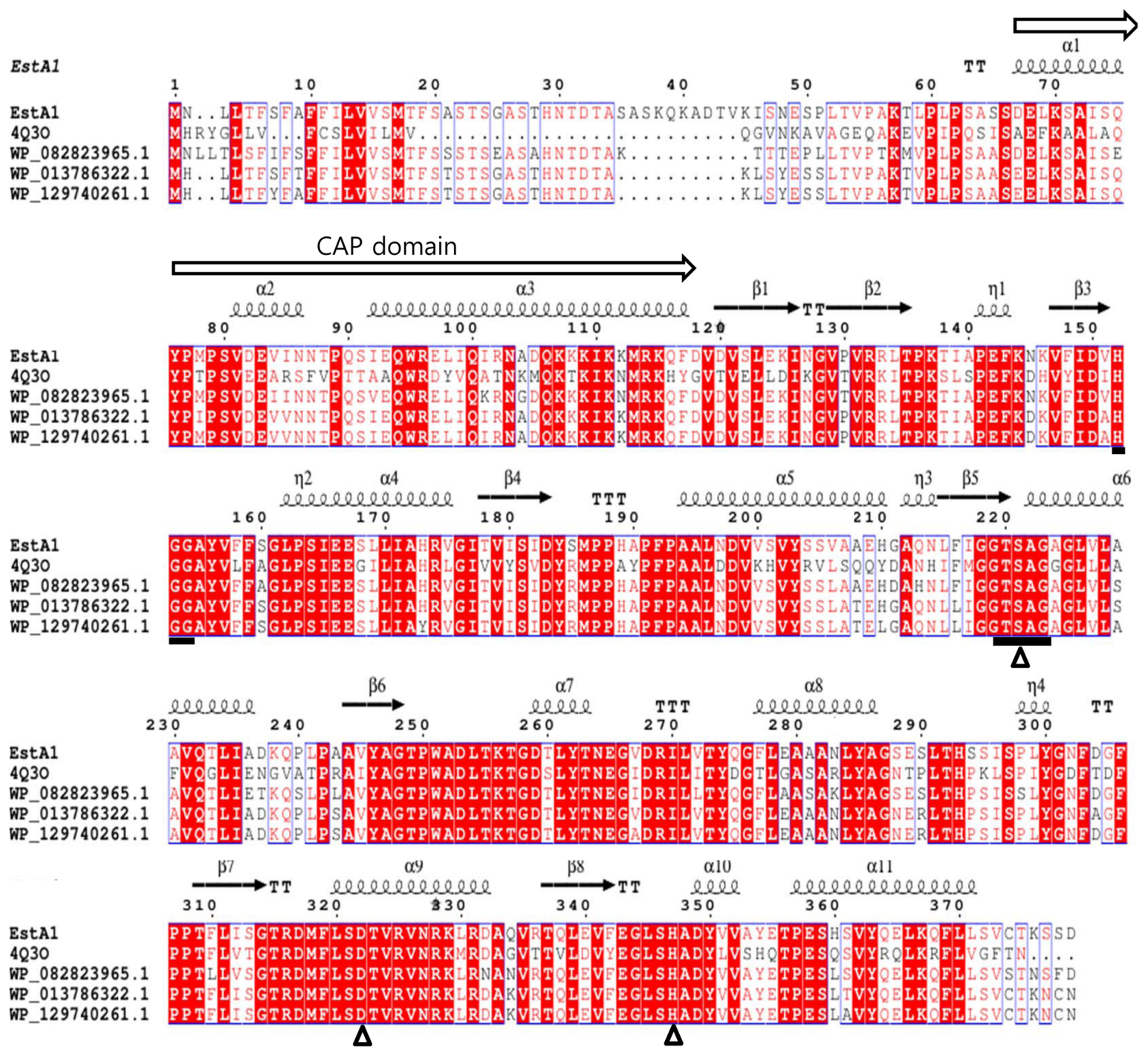

Fig. 1. Multiple sequence alignment of esterase EstA1 with other related enzymes.

4Q3O, MGS-MT1 $\alpha / \beta$ hydrolase from uncultured bacteria; WP_082823965.1, $\alpha / \beta$ hydrolase from Alteromonas stellipolaris; WP_013786322.1, $\alpha / \beta$ hydrolase from Alteromonas naphthalenivorans; WP_129740261.1 $\alpha / \beta$ hydrolase from Alteromonas sp. 76-1. Empty triangles $(\triangle)$ represent putative catalytic triad: S221, D317, H347. The $\alpha$-helix, $\beta$-sheet, random coil, beta turn represent as $\alpha, \beta, \eta$, and T, respectively. Black squares represent the oxyanion hole and pentapeptide near active site serine residue. White arrow represents Cap domain of esterase EstA1. Red boxes indicate regions with identical amino acid residues.

active site pocket and are identified as catalytic triads (Fig. S5). Interestingly, family IV enzymes are composed of a cap domain covering the active site and a catalytic domain that occupies most of the rest. This cap domain was known to be directly or indirectly associated with enzyme activity, specificity, regioselectivity, thermophilicity and thermostability [8]. The structure of the esterase EstAl is clearly divided into cap domain consisting of three helices $(\alpha 1, \alpha 2$, and $\alpha 3)$ and a catalytic domain containing the active site (Figs. 1 and S5).

\section{Expression and Purification of Recombinant Esterase EstA1}

The pET 22 vector was used to produce the esterase EstA1 in E. coli BL21 (DE3) cells. The intact protein with His6 tag at the C-terminal end was produced in E. coli cells, but the enzyme activity in cell-free extract was not high (12.1 U/mg protein) (Fig. 2A). Accordingly, the expected recombinant protein band was not detected in SDS-PAGE (Fig. 2B). To produce active esterase EstA1, we constructed two mutant proteins that partially removed its $\mathrm{N}$-terminal 
A

WT and mutants of esterase EstA1

Esterase activity of cell-free extract

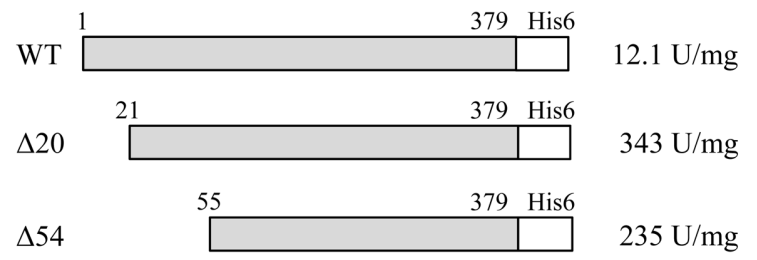

B

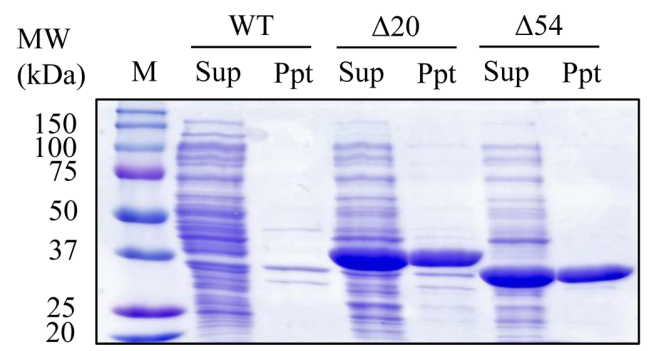

Fig. 2. Construction of mutant esterase EstA1 for protein expression in E. coli.

(A) Wild type (WT) and two mutants $(\Delta 20, \Delta 54)$ were constructed and the esterase activities of the three recombinant $E$. coli cell-free extracts were measured. (B) Protein profiles of the three recombinant E. coli cells were analyzed by SDS-PAGE. M, protein size marker; Sup, supernatant (cell-free extract); Ppt, pellet.

sequences. The SignalP 4.1 Server program predicted that the N-terminal signal sequence was located from $\mathrm{Met}^{1}$ to $\mathrm{Ser}^{20}$, so we prepared one mutant enzyme with the signal sequence removed $(\Delta 20)$. In addition, another mutant enzyme $(\Delta 54)$ was prepared by removing $\mathrm{N}$-terminal 54 amino acids by comparing with the Mgs-mt1 esterase (PDB: 4Q3O) which has already been revealed in its 3D structure. We tried to express the two mutants in E. coli BL21 (DE3) cells, and both showed significantly higher enzyme activity ( $343 \mathrm{U} / \mathrm{mg}$ for $\Delta 20$ mutant and $235 \mathrm{U} / \mathrm{mg}$ for $\Delta 54$ mutant) (Fig. 2A). We could also detect the expected sizes of the two soluble recombinant protein bands in SDSPAGE (Fig. 2B). In this study, both mutants were purified and their biochemical characteristics were investigated.

The mutant enzymes in E. coli cell-free extract were purified through Ni-NTA column chromatography and the residual imidazole was removed through gel permeation chromatography (Fig. 3). The specific activities of the finally purified mutant enzymes were $874 \mathrm{U} / \mathrm{mg}$ ( $\Delta 20$ mutant) and $711 \mathrm{U} / \mathrm{mg}$ ( $\Delta 54$ mutant) and the purification yields were calculated as $20 \%$ ( $\Delta 20$ mutant) and $43 \%$ ( $\Delta 54$ mutant) (Table S2).

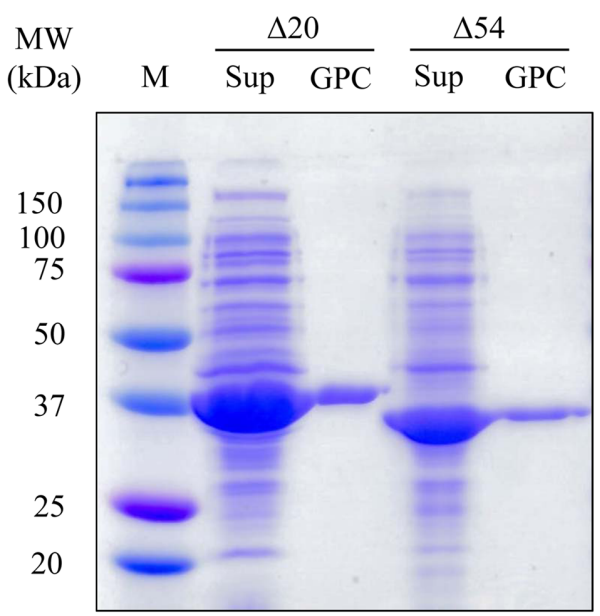

Fig. 3. SDS-PAGE analysis of the esterase EstA1.

Lane 1, protein size marker; Lane 2, cell-free extract of E. coli cells expressing $\Delta 20$ mutant; Lane 3, purified $\Delta 20$ mutant by $\mathrm{Ni}^{2+}$-NTA column and gel permeation chromatographies; Lane 4, cell-free extract of $E$. coli cells expressing $\Delta 54$ mutant; Lane 5, purified $\Delta 54$ mutant by $\mathrm{Ni}^{2+}$-NTA column and gel permeation chromatographies.

\section{Characterization of the $\Delta \mathbf{2 0}$ and $\Delta \mathbf{5 4}$ Mutants}

The substrate specificity of the $\Delta 20$ and $\Delta 54$ mutants was determined using $p$ NP-esters $\left(\mathrm{C}_{2}-\mathrm{C}_{8}\right)$ as substrates in Tris$\mathrm{HCl}$ buffer ( $\mathrm{pH} 8.0$ ) at $40^{\circ} \mathrm{C}$ (Fig. 4). Both $\Delta 20$ and $\Delta 54$ mutants hydrolyzed preferentially short-length acyl chain substrates. The highest specific activity was detected for $p$ NP-acetate $\left(C_{2}\right)$ and enzyme activity for $p$ NP-butyrate $\left(C_{4}\right)$ was less than $15 \%$ comparing with $p$ NP-acetate. However, esterase EstA1 rarely hydrolyzed longer chain lengths $\left(\mathrm{C}_{6}\right.$, $\mathrm{C}_{8}$ ) substrates. This feature indicates that both $\Delta 20$ and $\Delta 54$

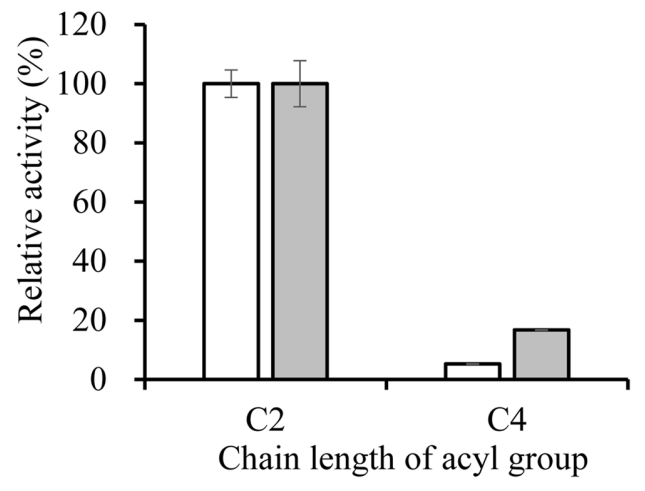

Fig. 4. Substrate specificity of the $\Delta 20$ and $\Delta 54$ mutants. Hydrolytic activity of $\Delta 20$ and $\Delta 54$ mutant was measured using pNP acetate (C2) and pNP butyrate (C4). Open bar, $\Delta 20$ mutant; filled bar, $\Delta 54$ mutant. 
A

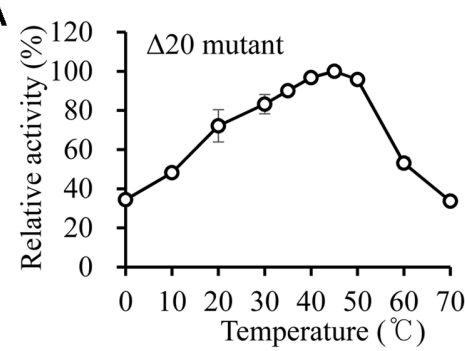

C

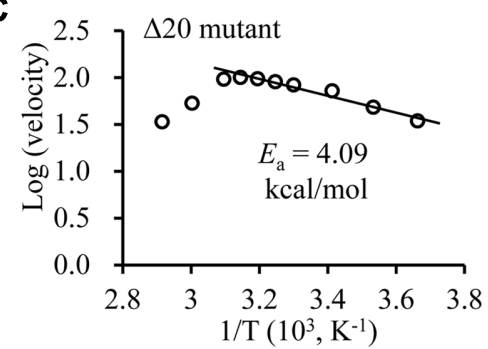

E

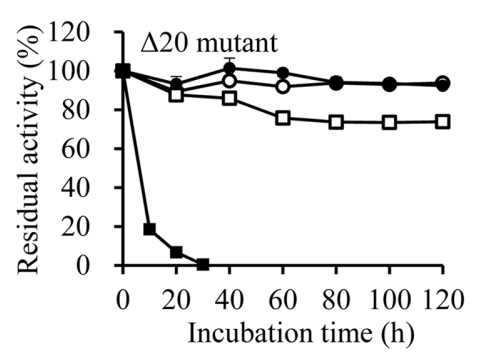

B

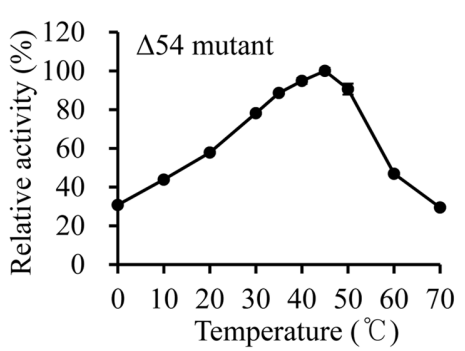

D

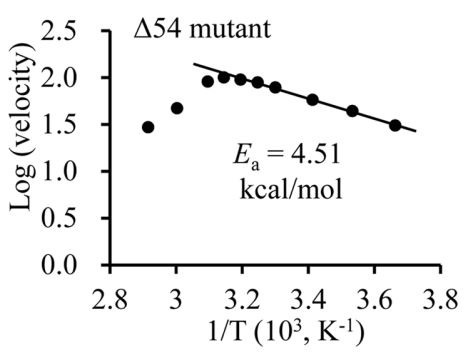

$\mathbf{F}$

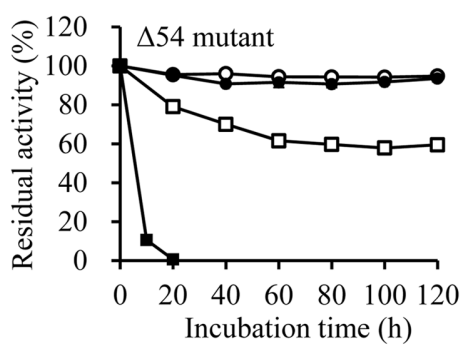

Fig. 5. Effects of temperature on the $\Delta 20$ and $\Delta 54$ mutants.

(A and B) The esterase activities of $\Delta 20$ and $\Delta 54$ mutants were measured at various temperatures. (C and D) Graphs were made using Arrhenius equation to obtain the activation energy of $\Delta 20$ and $\Delta 54$ mutant. (E and $\mathbf{F}$ ) The residual activities of $\Delta 20$ and $\Delta 54$ mutants were measured after heattreating in the various temperatures. $\bigcirc, 30^{\circ} \mathrm{C} ; 0,40^{\circ} \mathrm{C} ; \square, 50^{\circ} \mathrm{C} ; \mathbf{\square}, 55^{\circ} \mathrm{C}$

mutants have very narrow substrate specificity.

Despite their preference for $p \mathrm{NP}$-acetate, $p \mathrm{NP}$-butyrate was used to analyze optimal temperature and $\mathrm{pH}$, because $p \mathrm{NP}$-acetate was unstable in the wide temperature and $\mathrm{pH}$ range. The effect of temperature on the $\Delta 20$ and $\Delta 54$ mutant activity was measured at $0-70^{\circ} \mathrm{C}$ (Figs. $5 \mathrm{~A}$ and $5 \mathrm{~B}$ ). This enzyme was expected to be highly active at low temperatures because it was found in the Arctic Ocean, but the optimum reaction temperature was found to be $40^{\circ} \mathrm{C}$ when the relationship of temperature vs. activity was examined. Interestingly, they had $34 \%$ activity $(\Delta 20)$ and $30 \%$ activity $(\Delta 54)$ even at $0^{\circ} \mathrm{C}$, which indicated that the enzymes could work at low temperatures such as in the Arctic region. In addition, the activation energies $\left(E_{\mathrm{a}}\right)$ of the mutant enzymes were calculated as $4.09 \mathrm{kcal} / \mathrm{mol}(\Delta 20)$ and $4.51 \mathrm{kcal} / \mathrm{mol}(\Delta 54)$ in the temperature region from 0 to $40^{\circ} \mathrm{C}$ (Figs. 5C and 5D), which were very similar to the $E_{\mathrm{a}}$ values of typical cold-adapted enzymes [31]. Both $\Delta 20$ and $\Delta 54$ mutants were stable at $40^{\circ} \mathrm{C}$ for $120 \mathrm{~h}$ (Figs. $5 \mathrm{E}$ and $5 \mathrm{~F}$ ).
At $50^{\circ} \mathrm{C}$, the activity decreased to $74 \%(\Delta 20)$ and $59 \%(\Delta 54)$ after $120 \mathrm{~h}$-incubation. At $55^{\circ} \mathrm{C}$, most of the enzyme activity disappeared within $20 \mathrm{~h}$, but the $\Delta 20$ mutant was found to be relatively thermo-stable compared to the $\Delta 54$ mutant.

The effect of $\mathrm{pH}$ on the $\Delta 20$ and $\Delta 54$ mutant activity was measured at $40^{\circ} \mathrm{C}$ and $\mathrm{pH}$ 6.0-9.5 (Figs. 6A and 6B). Both mutant enzymes exhibited maximum activity at $\mathrm{pH} 8.0$ and relatively high activity in the $\mathrm{pH}$ range of 7.5-9.0, suggesting that this enzyme is an alkaline esterase. For $\mathrm{pH}$ stability, both mutant enzymes were relatively stable in the $\mathrm{pH}$ range of $\mathrm{pH}$ 5.5-10.0. However, their enzyme stabilities decreased sharply when $\mathrm{pH}$ was higher than 10.0 (Figs. 6C and 6D).

Effects of Organic Solvents, Metal Ions, Inhibitors, and Detergents on $\Delta 20$ and $\Delta \mathbf{5 4}$ Mutants

The activities of the $\Delta 20$ and $\Delta 54$ mutants were measured with several organic solvents, metal ions, inhibitors, and detergents. First, both mutants showed high stability up to $15 \%$ concentration of most organic solvents (Table 1). But 

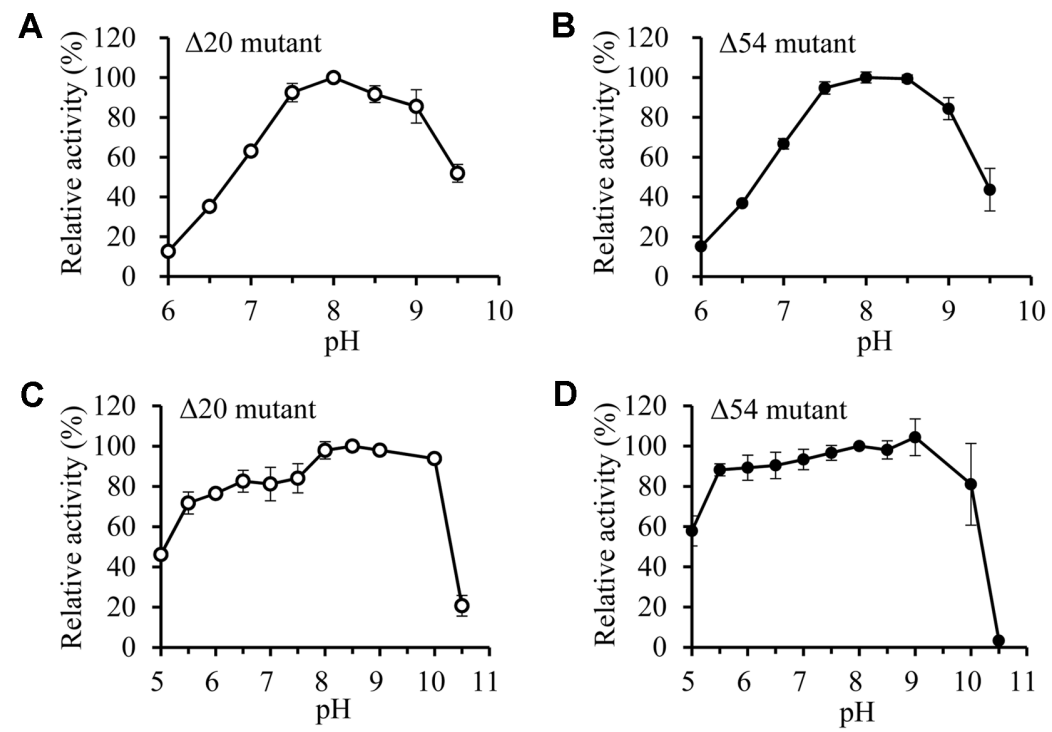

Fig. 6. Effects of $\mathrm{pH}$ on the $\Delta 20$ and $\Delta 54$ mutants.

(A and B) The esterase activities of $\Delta 20$ and $\Delta 54$ mutants were measured at various pHs. (C and D) The residual activities of $\Delta 20$ and $\Delta 54$ mutants were measured after 30 min-incubation in the various $\mathrm{pH}$ buffers. $\mathrm{pH}$ 5.0-6.0, $50 \mathrm{mM}$ sodium acetate; $\mathrm{pH}$ 6.0-8.0, $50 \mathrm{mM}$ potassium phosphate; $\mathrm{pH}$ 8.0-9.0, $50 \mathrm{mM}$ Tris-HCl; $\mathrm{pH}$ 9.0-10.5, $50 \mathrm{mM}$ carbonate-bicarbonate.

they had reduced activity in acetonitrile solvent. When the concentration of organic solvents increased to $30 \%$, this enzyme showed stability only in DMSO, methanol, cyclohexane, and n-hexane. When the concentration of organic solvents increased to $50 \%$, the mutant enzymes still showed high stability in DMSO, cyclohexane, and n-hexane, suggesting that these enzymes are organic solvent-tolerant enzymes.

Both mutant enzymes exhibited high activity on many metal ions. The enzyme activity was maintained at the concentrations of $1 \mathrm{mM}$ and $5 \mathrm{mM}$ of metal ions $\left(\mathrm{Li}^{+}, \mathrm{Na}^{+}\right.$, $\mathrm{K}^{+}, \mathrm{Mg}^{2+}, \mathrm{Ca}^{2+}, \mathrm{Co}^{2+}$, and $\mathrm{Ni}^{+}$), however, enzyme activity was significantly reduced at the concentrations of $5 \mathrm{mM}$ of

Table 1. Effects of organic solvents on the EstA1 esterase.

\begin{tabular}{lccccccc}
\hline \multirow{2}{*}{ Solvent } & \multirow{2}{*}{$\log \mathrm{P}$} & \multicolumn{3}{c}{$\Delta 20$ mutant } & \multicolumn{3}{c}{$\Delta 54$ mutant } \\
\cline { 3 - 8 } & & $15 \%$ & $30 \%$ & $50 \%$ & $15 \%$ & $30 \%$ & $50 \%$ \\
\hline None & 100 & 100 & 100 & 100 & 100 & 100 \\
DMSO & -1.3 & 106 & 101 & 98 & 81 & 101 & 88 \\
Methanol & -0.76 & 100 & 94 & $\mathrm{ND}$ & 83 & 71 & $\mathrm{ND}$ \\
Acetonitrile & -0.33 & 68 & $\mathrm{ND}$ & $\mathrm{ND}$ & 39 & $\mathrm{ND}$ & $\mathrm{ND}$ \\
Ethanol & -0.24 & 87 & 7 & $\mathrm{ND}$ & 86 & $\mathrm{ND}$ & $\mathrm{ND}$ \\
Acetone & -0.23 & 108 & 66 & $\mathrm{ND}$ & 112 & 55 & $\mathrm{ND}$ \\
Isopropanol & 0.1 & 102 & $\mathrm{ND}$ & $\mathrm{ND}$ & 103 & $\mathrm{ND}$ & $\mathrm{ND}$ \\
Cyclohexane & 3.2 & 101 & 131 & 135 & 119 & 127 & 147 \\
n-Hexane & 3.5 & 103 & 121 & 159 & 108 & 119 & 131 \\
\hline *ND, not & & & & & & &
\end{tabular}

${ }^{*} \mathrm{ND}$, not detected some metal ions $\left(\mathrm{Zn}^{2+}\right.$ and $\left.\mathrm{Cu}^{2+}\right)$ (Table 2). These ions are expected to have the ability to inhibit the enzyme activity of esterase/lipase. Enzyme activity of metagenome esterase E25 [32], metagenome esterase E40 [33], Alkalibacterium esterase rEstSL3 [34], and metagenome esterase H8 [35] tended to decrease in the presence of these metal ions, indicating that they are potential inhibitors to esterase/ lipase.

Their enzyme activities were maintained against some chemical agents (DTT, $\beta$-ME, GSSG, EDTA, and PMSF) at low concentration $(1 \mathrm{mM})$ (Figs. $7 \mathrm{~A}$ and $7 \mathrm{~B})$. However, their activities were significantly reduced against reducing agents (DTT and $\beta-\mathrm{ME}$ ) and serine protease inhibitor

Table 2. Effects of metal ions on the EstA1 esterase.

\begin{tabular}{lcccc}
\hline \multirow{2}{*}{ Ion } & \multicolumn{2}{c}{$\Delta 20$ mutant } & \multicolumn{2}{c}{$\Delta 54$ mutant } \\
\cline { 2 - 5 } & $1 \mathrm{mM}$ & $5 \mathrm{mM}$ & $1 \mathrm{mM}$ & $5 \mathrm{mM}$ \\
\hline $\mathrm{None}$ & 100 & 100 & 100 & 100 \\
$\mathrm{LiCl}$ & 102 & 100 & 101 & 101 \\
$\mathrm{NaCl}$ & 96 & 93 & 103 & 103 \\
$\mathrm{~K}_{2} \mathrm{SO}_{4}$ & 101 & 103 & 101 & 104 \\
$\mathrm{MgCl}_{2}$ & 98 & 101 & 102 & 101 \\
$\mathrm{CaCl}_{2}$ & 101 & 99 & 104 & 103 \\
$\mathrm{CoCl}_{2}$ & 99 & 101 & 96 & 109 \\
$\mathrm{NiSO}_{4}$ & 99 & 97 & 97 & 89 \\
$\mathrm{ZnSO}_{4}$ & 92 & 79 & 87 & 58 \\
$\mathrm{CuSO}_{4}$ & 89 & 79 & 90 & 69 \\
\hline
\end{tabular}


A

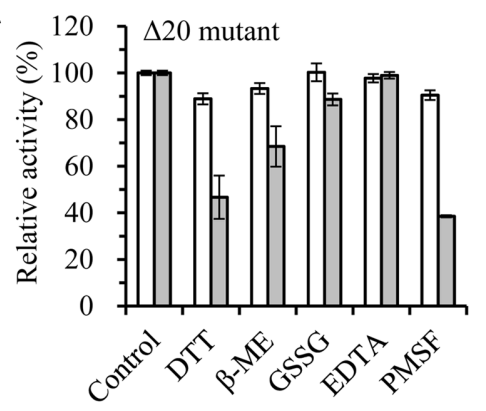

C

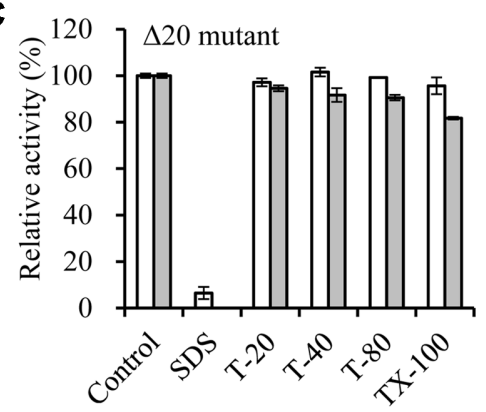

B
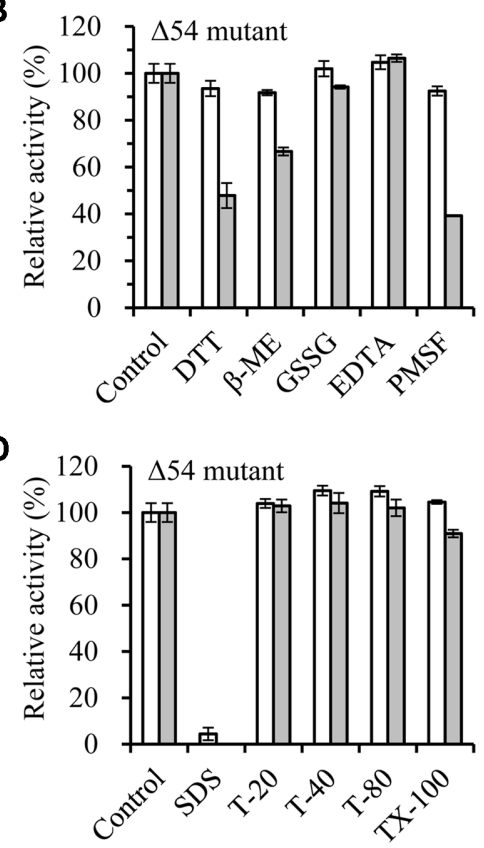

Fig. 7. Effects of inhibitor and detergent on the $\Delta 20$ and $\Delta 54$ mutants.

(A and B) The residual activities of $\Delta 20$ and $\Delta 54$ mutants were measured after incubation in various inhibitors. Open bar, $1 \mathrm{mM}$; closed bar, $5 \mathrm{mM}$. (C and D) The residual activities of $\Delta 20$ and $\Delta 54$ mutants were measured after incubation in various detergents. Open bar, $0.1 \%$; filled bar, $0.5 \%$.

(PMSF) at high concentration $(5 \mathrm{mM})$, indicating that serine residue is present in the active site of this enzyme. These enzymes exhibited high stability at concentration of $0.1 \%$ and $0.5 \%$ of most neutral detergents including T-20, T-40, T-80, and TX-100. But the enzyme activity was greatly

\section{A}

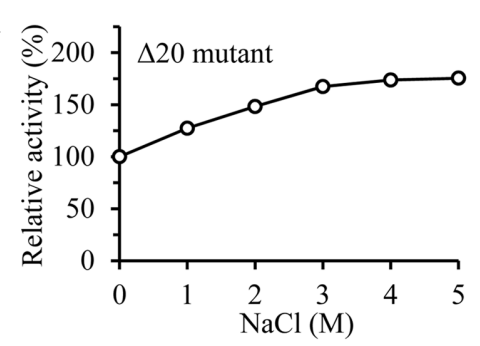

\section{C}

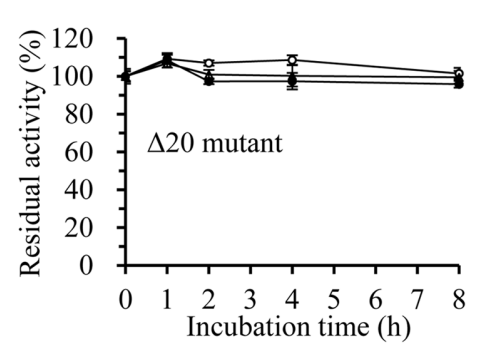

reduced by $0.1 \%$ concentration of SDS, an anionic detergent (Figs. 7C and 7D).

Effect of $\mathrm{NaCl}$ on $\Delta 20$ and $\Delta 54$ Mutant Activity and Stability Since the enzyme was isolated from Arctic marine

B
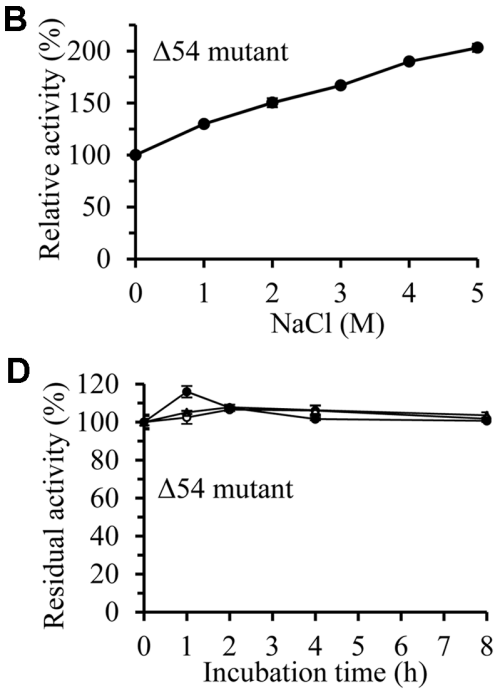

Fig. 8. Effects of $\mathrm{NaCl}$ on the $\Delta 20$ and $\Delta 54$ mutants.

(A and B) The esterase activities of $\Delta 20$ and $\Delta 54$ mutants were measured at various $\mathrm{NaCl}$ concentrations. (C and D) The residual activities of $\Delta 20$ and $\Delta 54$ mutants were measured after incubation in $\mathrm{NaCl}$ solution. $\bigcirc, 3 \mathrm{M} \mathrm{NaCl}$;

, $4 \mathrm{M} \mathrm{NaCl} ; \triangle, 5 \mathrm{M} \mathrm{NaCl}$. 
microorganisms, it was expected to have stability and activity against high concentration of $\mathrm{NaCl}$. The activities of the $\Delta 20$ and $\Delta 54$ mutants were continuously increased with increasing $\mathrm{NaCl}$ concentration and enzyme activities were measured to be $175 \%(\Delta 20)$ and $203 \%(\Delta 54)$ at $5 \mathrm{M} \mathrm{NaCl}$ concentration (Figs. $8 \mathrm{~A}$ and $8 \mathrm{~B}$ ). This enzyme maintained its activity for $8 \mathrm{~h}$ in the presence of $3 \mathrm{M}, 4 \mathrm{M}$, and $5 \mathrm{M}$ $\mathrm{NaCl}$ (Figs. 8C and 8D). Water molecules are essential for protein conformation and function and prevent protein aggregation [36]. High concentrations of salt ions in aqueous solutions reduce the number of water molecules available to the protein, making it impossible for the protein to be hydrated [37]. This phenomenon is analogous to the reduction of water molecules available to proteins by organic solvents. However, halophilic proteins can retain their structure and maintain their enzymatic activity even when the salt ions are increased [23]. Some halophilic enzymes may exhibit better activity under high salt concentration. Salt concentrations may significantly affect the folding, conformation, subunit structure, and kinetics of halophilic proteins. Since this enzyme has high activity and stability in high salt concentration, the study of its structure and activity is considered to be academically and industrially meaningful.

Taken together, new enzyme esterase EstA1 was isolated from the Arctic Alteromonas sp. 39-G1 strain. We failed to express the wild type of this enzyme in E. coli, but succeeded in producing mutant enzymes ( $\Delta 20$ and $\Delta 54)$ as active forms. Both $\Delta 20$ and $\Delta 54$ mutants were purified and characterized for the first time in this research. These mutant enzymes were found to have cold-adapted, alkaline, and salt-tolerant properties, so we think that they are very likely to be used academically and industrially.

\section{Acknowledgements}

This work was supported by the Korea Polar Research Institute (PE18100) and the Basic Science Research Program through the National Research Foundation of Korea (NRF) funded by the Ministry of Education (NRF2018R1D1A1B07047529). This work was also supported by the Research Fund 2019 of The Catholic University of Korea.

\section{Conflict of Interest}

The authors have no financial conflicts of interest to declare.

\section{References}

1. Anthonsen HW, Baptista A, Drabløs F, Martel P, Petersen SB, Sebastião M, et al. 1995. Lipases and esterases: a review of their sequences, structure and evolution, Biotechnol. Annu. Rev. 1: 315-371.

2. Nardini M, Dijkstra BW. 1999. $\alpha / \beta$ Hydrolase fold enzymes: the family keeps growing. Curr. Opin. Struct. Biol. 9: 732-737.

3. Bornscheuer UT. 2002. Microbial carboxyl esterases: classification, properties and application in biocatalysis. FEMS Microbiol. Rev. 26: 73-81.

4. Fu J, Leiros HK, de Pascale D, Johnson KA, Blencke HM, Landfald B. 2013. Functional and structural studies of a novel cold-adapted esterase from an Arctic intertidal metagenomic library. Appl. Microbiol. Biotechnol. 97: 3965-3978.

5. Kim HJ, Jeong YS, Jung WK, Kim SK, Lee HW, Kahng HY, et al. 2015. Characterization of novel family IV esterase and family I. 3 lipase from an oil-polluted mud flat metagenome. Mol. Biotechnol. 57: 781-792.

6. Arpigny JL, Jaeger KE. 1999. Bacterial lipolytic enzymes: classification and properties. Biochem. J. 343: 177-183.

7. Hemilä H, Koivula TT, Palva I. 1994. Hormone-sensitive lipase is closely related to several bacterial proteins, and distantly related to acetylcholinesterase and lipoprotein lipase: Identification of a superfamily of esterases and lipases. Biochim. Biophys. Acta 1210: 249-253.

8. Mandrich L, Merone L, Pezzullo M, Cipolla L, Nicotra F, Rossi $\mathrm{M}$, et al. 2005. Role of the $\mathrm{N}$ terminus in enzyme activity, stability and specificity in thermophilic esterases belonging to the HSL family. J. Mol. Biol. 345: 501-512.

9. Nam KH, Kim MY, Kim SJ, Priyadarshi A, Lee WH, Hwang KY. 2009. Structural and functional analysis of a novel EstE5 belonging to the subfamily of hormone-sensitive lipase. Biochem. Biophys. Res. Commun. 379: 553-556.

10. Rhee JK, Ahn DG, Kim YG, Oh JW. 2005. New thermophilic and thermostable esterase with sequence similarity to the hormone-sensitive lipase family, cloned from a metagenomic library. Appl. Environ. Microbiol. 71: 817-825.

11. Ferrer M, Golyshina OV, Chernikova TN, Khachane AN, Martins dos Santos VA, Yakimov MM, et al. 2005. Microbial enzymes mined from the urania deep-sea hypersaline anoxic basin. Chem. Biol. 12: 895-904.

12. Jeon JH, Kim JT, Kang SG, Lee JH, Kim SJ. 2009. Characterization and its potential application of two esterases derived from the Arctic sediment metagenome. Mar. Biotechnol. 11: 307-316.

13. Hu Y, Fu C, Huang Y, Yin Y, Cheng G, Lei F, et al. 2010. Novel lipolytic genes from the microbial metagenomic library of the South China Sea marine sediment. FEMS Microbiol. Ecol. 72: 228-237.

14. Bunterngsook B, Kanokratana $\mathrm{P}$, Thongaram T, Tanapongpipat S, Uengwetwanit T, Rachdawong S, et al. 2010. Identification 
and characterization of lipolytic enzymes from a peat-swamp forest soil metagenome. Biosci. Biotechnol. Biochem. 74: 1848-1854.

15. Hough DW, Danson MJ. 1999. Extremozymes. Curr. Opin. Chem. Biol. 3: 39-46.

16. Adams MWW, Perler FB, Kelly RM. 1995. Extremozymes: Expanding the limits of biocatalysis. Biotechnology. 13: 662-668.

17. Gomes JS, Walter. 2004. The biocatalytic potential of extremophiles and extremozymes. Food Technol. Biotechnol. 42: 223-235.

18. Bowers KJ, Mesbah NM, Wiegel J. 2009. Biodiversity of poly-extremophilic bacteria: does combining the extremes of high salt, alkaline $\mathrm{pH}$ and elevated temperature approach a physico-chemical boundary for life? Saline Systems. 5: 9.

19. Pire C, Marhuenda-egea FC, Esclapez J, Alcaraz L, Ferrer J, José Bonete M. 2004. Stability and enzymatic studies of glucose dehydrogenase from the archaeon Haloferax mediterranei in reverse micelles. Biocatal. Biotransformation. 22: $17-23$.

20. Demirjian DC, Morı's-Varas F, Cassidy CS. 2001. Enzymes from extremophiles. Curr. Opin. Chem. Biol. 5: 144-151.

21. Trincone A. 2011. Marine biocatalysts: enzymatic features and applications. Mar. Drugs 9: 478-499.

22. Fuciños P, González R, Atanes E, Sestelo ABF, Pérez-Guerra $\mathrm{N}$, Pastrana L, et al. 2012. Lipases and esterases from extremophiles: overview and case example of the production and purification of an esterase from Thermus thermophilus HB27, pp. 239-266. In Sandoval G (ed.), Lipases and phospholipases: Methods and Protocols, Ed. Humana Press, Totowa, NJ.

23. Karan R, Capes MD, DasSarma S. 2012. Function and biotechnology of extremophilic enzymes in low water activity. Aqua. Biosyst. 8: 4.

24. Panda T, Gowrishankar B. 2005. Production and applications of esterases. Appl. Microbiol. Biotechnol. 67: 160-169.

25. Jegannathan KR, Nielsen PH. 2013. Environmental assessment of enzyme use in industrial production-a literature review. J. Clean. Prod. 42: 228-240.

26. Ramnath L, Sithole B, Govinden R. 2016. Classification of lipolytic enzymes and their biotechnological applications in the pulping industry. Can. J. Microbiol. 63: 179-192.
27. Rao TE, Imchen M, Kumavath R. 2017. Marine enzymes: production and applications for human health. Adv. Food Nutr. Res. 80: 149-163.

28. Sasso F, Natalello A, Castoldi S, Lotti M, Santambrogio C, Grandori R. 2016. Burkholderia cepacia lipase is a promising biocatalyst for biofuel production. Biotechnol. J. 11: 954-960.

29. Yang SZ, Jin HJ, Wei Z, He RX, Ji YJ, Li XM, et al. 2009. Bioremediation of oil spills in cold environments: a review. Pedosphere. 19: 371-381.

30. Alcaide M, Stogios PJ, Lafraya Á, Tchigvintsev A, Flick R, Bargiela $R$, et al. 2015. Pressure adaptation is linked to thermal adaptation in salt-saturated marine habitats. Environ. Microbiol. 17: 332-345.

31. Kulakova L, Galkin A, Nakayama T, Nishino T, Esaki N. 2004. Cold-active esterase from Psychrobacter sp. Ant300: gene cloning, characterization, and the effects of Gly->Pro substitution near the active site on its catalytic activity and stability. Biochim. Biophys. Acta 1696: 59-65.

32. Li PY, Ji P, Li CY, Zhang Y, Wang GL, Zhang XY, et al. 2014. Structural basis for dimerization and catalysis of a novel esterase from the GTSAG motif subfamily of the bacterial hormone-sensitive lipase family. J. Biol. Chem. 289: 19031-19041.

33. Li PY, Chen XL, Ji P, Li CY, Wang P, Zhang Y, et al. 2015. Interdomain hydrophobic interactions modulate the thermostability of microbial esterases from the hormonesensitive lipase family. J. Biol. Chem. 290: 11188-11198.

34. Wang G, Wang Q, Lin X, Bun Ng T, Yan R, Lin J, Ye X. 2016. A novel cold-adapted and highly salt-tolerant esterase from Alkalibacterium sp. SL3 from the sediment of a soda lake. Sci. Rep. 6: 19494.

35. Zhang Y, Hao J, Zhang YQ, Chen XL, Xie BB, Shi M, et al. 2017. Identification and characterization of a novel salttolerant esterase from the deep-sea sediment of the South China Sea. Front. Microbiol. 8: 441.

36. Kuntz Jr ID. 1971. Hydration of macromolecules. IV. Polypeptide conformation in frozen solutions. J. Am. Chem. Soc. 93: 516-518.

37. Persson E, Halle B. 2008. Cell water dynamics on multiple time scales. Proc. Natl. Acad. Sci. USA 105: 6266-6271. 